
3 Research Square
Preprints are preliminary reports that have not undergone peer review.
They should not be considered conclusive, used to inform clinical practice, or referenced by the media as validated information.

\title{
Early Identification of Acute Kidney Injury in the Icu With Real-time Urine Output Monitoring: A Clinical Investigation
}

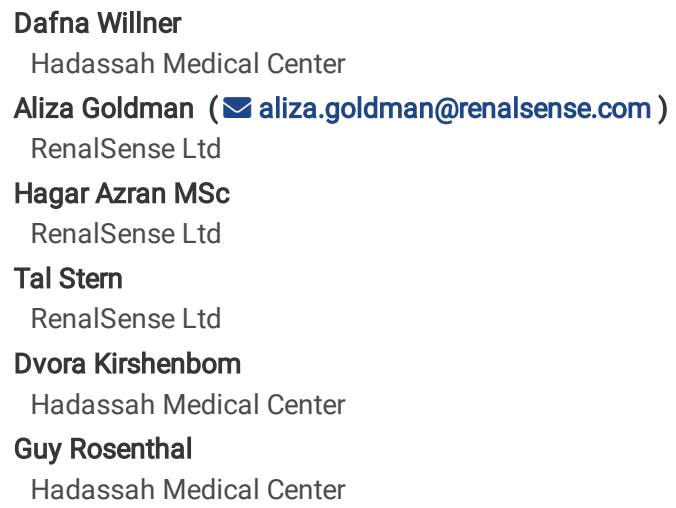

Research Article

Keywords: acute kidney injury, KDIGO criteria, oliguria, urine output, electronic monitoring, serum creatinine, length of stay

Posted Date: April 9th, 2021

DOI: https://doi.org/10.21203/rs.3.rs-394989/v1

License: (c) (1) This work is licensed under a Creative Commons Attribution 4.0 International License. Read Full License 


\section{Abstract}

Background

The inconsistencies in classifying AKI according to the KDIGO (Kidney Disease: Improving Global Outcomes) urine output (UO) criteria have prevented an accurate assessment of the role this easily available biomarker can play in the early identification of AKI. Study goal: To assess and compare the performance of the two KDIGO criteria ( $\mathrm{SCr}$ and $\mathrm{UO}$ ) for early identification of AKI in the intensive care unit (ICU) by comparing the standard SCr criteria to real-time, consecutive, electronic urine output measurements.

Methods

95 catheterized patients in the GICU of Hadassah Medical Center, Israel were connected to The RenalSense ${ }^{\text {TM }}$ Clarity RMS $^{\text {TM }}$ sensor kit to monitor UO electronically $\left(\mathrm{UO}_{\text {elec }}\right)$. $\mathrm{UO}_{\text {elec }}$ and $\mathrm{SCr}$ were recorded between $24-48$ hours and up to one week, respectively, after ICU admission.

Results

Real-time consecutive UO measurements identified significantly more AKI patients than $\mathrm{SCr}$ in the patient population, $57.9 \%(\mathrm{~N}=55)$ versus $26.4 \%$ ( $\mathrm{N}=25$ ), respectively $(\mathrm{P}<0.0001)$. In 20 patients that had $\mathrm{AKI}$ according to both criteria, time to $\mathrm{AKI}$ identification was significantly earlier by the $\mathrm{UO}_{\text {elec }}$ criteria as compared to the $\mathrm{SCr}$ criteria $(\mathrm{P}<0.0001)$. Among this population, the median (IQR) identification time of AKI UO elec was $12.75(8.75,26.25)$ hours from ICU admission and $39.06(25.8,108.64)$ hours for AKI SCr.

Conclusion

Application of KDIGO criteria for AKI using continuous electronic monitoring of UO identifies more AKI patients, and identifies them earlier, than using the SCr criteria alone. This application can enable the clinician to set protocol goals for earlier intervention of the treatment of AKI.

\section{Background}

Studies using the KDIGO (Kidney Disease: Improving Global Outcomes) criteria have identified AKI in up to $75 \%$ of critically ill hospitalized patients (1). These criteria classify acute kidney injury (AKI) based on: a rise in serum creatinine (SCr), a decrease in urine output (UO) over time, or both $(2,3,4)$.

In the intensive care unit (ICU) neither of these indicators for AKI provides timely information about kidney injury. They are dependent on the times manually measured and recorded by the medical staff. Furthermore, SCr measurements are affected by many individual factors of the hospitalized patient. Most importantly, SCr levels increase only after approximately $50 \%$ loss of renal function, and is thus recognized as a late indicator for kidney injury (5, 6 , 7 ). As for UO, KDIGO defines oliguria as a urine output of less than $0.5 \mathrm{ml} / \mathrm{kg}$ over 6 hours and AKI severity is established according to their guidelines for extended periods of oliguria. Unfortunately, the application of the KDIGIO UO criteria has been inconsistent $(1,2,3,4)$. Additionally, a recent review comparing KDIGO criteria to its predecessors (RIFLE (Risk, Injury, Failure, Loss and End stage disease) and AKIN (Acute Kidney Injury Network)), has shown that the reported incidence of AKI varies depending on how the criteria are applied (8).

There have been limited prospective studies applying the AKI UO criteria, and even less have incorporated both SCr and UO criteria. The studies also vary in how they record and assess UO. Some studies have applied the UO criteria as an average UO over 6, 12, and 24 hour intervals, using either blocks or continuous windows. Others have interpolated data by averaging UO over the missing hours in nursing records. Oftentimes, there is no indication at all of how UO measurements used in the study were recorded $(1,7,9,10,11)$. This lack of uniformity in recording, measurement, application and reporting of UO makes it difficult to draw consistent conclusions from the studies that use them.

It is not surprising, therefore, that the vast majority of retrospective studies to explore AKI using severity scores have applied only the SCr criteria. The few studies to include UO alongside SCr have either used 24-hour averages, applied UO criteria only when available, or simply excluded patients from the study group when there was no UO measurement available $(8,11,12,13,14)$. The resultant inconsistencies in classifying AKI according to UO have hindered the use of this easily available biomarker for early identification of AKI.

To address this gap in the research, a prospective study was designed using a novel, real-time measurement tool in order to consistently apply the KDIGO UO criteria for AKI as defined in the KDIGO guidelines (15). These criteria were also compared to the more commonly applied SCr criteria to identify AKI in the ICU patient.

\section{Study goal}

To assess and compare the performance of the two KDIGO criteria ( $\mathrm{SCr}$ and $\mathrm{UO}$ ) for early identification of AKI in the ICU by comparing the standard SCr criteria to real-time, consecutive electronic urine output measurements.

\section{Methods Study Design}

95 catheterized patients hospitalized in the General ICU at Hadassah Medical Center, Jerusalem, Israel were enrolled in a pilot study between August 2015 and Nov 2018. Local IRB approval was obtained and informed consent was waived. Inclusion criteria: Patients $\geq 18$ years of age, SCr baseline within normal range 
prior to commencement of $\mathrm{UO}_{\text {elec }}$ observations. Exclusion criteria: Patients isolated with bacterial infections such as methicillin-resistant staphylococcus aureus (MRSA), vancomycin-resistant enterococcus (VRE), and Klebsiella; patients likely to be discharged or die within 24 hours in the ICU; patients on dialysis; and pregnant women.

\section{Patient Characteristics}

Patient information included age, weight, baseline serum creatinine and daily serum creatinine measurements, primary diagnosis, co-morbidities, the need for mechanical ventilation, and the use of vasoactive drugs were recorded for 7 days or up until discharge from the ICU.

\section{The RenalSense ${ }^{\mathrm{mM}}$ Clarity RMS Sensor Kit ${ }^{\mathrm{TM}}$}

The RenalSense ${ }^{\text {TM }}$ Clarity RMS ${ }^{\text {TM }}$ was used to electronically monitor urine output every hour, and its technology is described elsewhere (15) (Fig. 1). The data for the validation of the system was obtained from the first group of patients enrolled in this study. The electronic measurements were compared to manual UO measurements and the results were published elsewhere (15). In brief, a total of 1,046 hours of electronic measurements recorded from 23 subjects measured with the RenalSense system were shown to be closer, with a better correlation, and narrower limits of agreement than the measurements obtained by the nurses, as compared to the scientific scale data (15). For the purposes of this study the Clarity RMS Sensor Kit was modified to incorporate a standard urinometer for the nursing staff to record UO as per the standard practice of the ICU. Additionally, the sensor was connected by a cable to a RenalSensedesigned data collection subsystem (DCS), and nursing staff was blinded to the Clarity RMS measurements. No information recorded had any bearing on the medical staff records, treatment interventions, or medical decisions for the patient. The drainage bag was placed in a container on a scientific scale (Precisa BJ 2200C) to be used as the reference for validation of the sensor measurements. The scale data was also recorded continuously by the same system.

\section{AKI analysis}

AKI was identified and scored according to the KDIGO criteria for SCr and UO (2). KDIGO Stage 1 was an increase in SCr by $\geq 0.3 \mathrm{mg} / \mathrm{dl}$ ( $\geq 26.5 \mathrm{~mol} / \mathrm{I}$ ) within $48 \mathrm{~h}$ or an increase in SCr to $1.5-1.9$ times baseline or urine volume $<0.5 \mathrm{ml} / \mathrm{kg} / \mathrm{h}$ for at least $6 \mathrm{~h}$ and up to $12 \mathrm{~h}$. Stage 2 was an increase in SCr to $2.0-2.9$ times baseline or urine volume $<0.5 \mathrm{ml} / \mathrm{kg} / \mathrm{h}$ for $\geq 12 \mathrm{~h}$. Stage 3 was $\mathrm{SCr}>3.0$ times baseline or initiation of renal replacement therapy (RRT) or urine volume $<0.3 \mathrm{ml} / \mathrm{kg} / \mathrm{h}$ for $\geq 24 \mathrm{~h}$ or anuria for $\geq 12 \mathrm{~h}$. More than $50 \%$ of patients had no electronic record of SCr prior to hospital entry therefore a uniform definition baseline SCr was defined as the first serum creatinine drawn upon ICU admission. Patients diagnosed in their medical records with chronic kidney injury as identified by their SCr were included if there was no evidence of "acute on chronic" kidney injury (increased SCr upon initial ICU admission). SCr measurements were collected twice daily by the nurses according to department protocol and patients were treated accordingly as per standard of care. SCr measurements for the study included twice daily measurements for up to seven days following Clarity RMS removal if they remained in the ICU. Patients were connected to the Clarity RMS sensor kit upon admission to the ICU for a minimum of 24 hours. AKI staging was applied to patient UO monitored consecutively and electronically up to 48 hours after admission to the ICU. Identification of AKI: AKI was diagnosed at the end of the 6th hour of oliguria as defined by the first stage of the KDIGO criteria $\left(\mathrm{AKI} \mathrm{UO}_{\text {elec }}\right.$ versus non $\left.\mathrm{AKI} \mathrm{UO}_{\text {elec }}\right)$. The population was then analyzed again to identify kidney injury as an increase of SCr in patient records as defined by the first stage of the KDIGO criteria (AKI SCr versus non AKI SCr). Outcomes: For the analysis relating to outcomes the population was divided into 3 mutually exclusive groups to isolate the AKI patients identified only by the $\mathrm{UO}_{\text {elec }}$ criteria: AKI all-SCr (included patients that had AKI according to $\mathrm{UO}_{\text {elec }}$ in addition to $\mathrm{SCr}$ ) AKI only- $\mathrm{UO}_{\text {elec }}$ (excluded patients that also had AKI according to SCr) and non AKI-all, (excluded patients in either of the previous groups). Length of stay (LOS) in the ICU and hospital, hospital readmissions within 3 months of ICU discharge, and all-cause mortality, were recorded during the entire length of the study and up to a year after the study was completed.

\section{Statistical Analysis}

Baseline characteristics for the study population are presented. For continuous variables, mean, standard deviation (SD), median and IQR (interquartile range) were presented. For dichotomous variables, count and proportion were presented. Rate of AKI is described according to various identification groups and a comparison between the rate of $\mathrm{UO}_{\text {elec }}$ identification and SCr identification were performed using a paired signed-rank test. For all patients with AKI, time to identification was presented using the Kaplan-Meier curves. Comparison between the different measures' identification times was performed using the logrank test. This analysis was repeated for the patients identified by both $\mathrm{UO}_{\text {elec }}$ and $\mathrm{SCr}$. Comparison between AKI identification groups were performed using the Wilcoxon rank sum test. Length of stay in the ICU and general hospitalization were presented by mean, SD, median, IQR, and range. In order to account for mortality as censored data, sensitivity analyses were performed analyzing these parameters as time to discharge, using Kaplan-Meier curves and the log-rank test. These analyses were repeated for subpopulations by age. No adjustment for multiple comparisons was performed. All analyses were performed using $\mathrm{R}$ 3.6.2.

\section{Results}

\section{Patient Characteristics}

The patient population was $67 \%$ male and $37 \%$ of the population was over 70 years of age with a median age of 63 . As expected, in the general ICU, the majority of the patients in our study group were surgical (67\%). Patient characteristics including comorbidities and AKI risk factors are shown in Table 1.

\section{Identification of $A K I$}

Application of the KDIGO criteria using either $\mathrm{SCr}$ or $\mathrm{UO}_{\text {elec }}$ or both, identified AKI in a total of 60 out of the 95 (62.5\%) patients in the study group. AKI UO ${ }_{\text {elec }}$ was identified in $57.9 \%(\mathrm{~N}=55)$ of the patient population. AKI SCr was identified in $26.4 \%(\mathrm{~N}=25)$ of the patient population; 20 patients had AKI according to 
both $\mathrm{UO}_{\text {elec }}$ and SCr criteria, and 5 were identified only by SCr criteria. $\mathrm{UO}_{\text {elec }}$ measurements alone identified 35 more AKI patients than the SCr criteria (Fig $2 \mathrm{a}$ ). Out of the $60 \mathrm{AKI}$ patients, $\mathrm{UO}_{\text {elec }}$ identified significantly more patients than serum creatinine, $92 \%$ versus $42 \%$, respectively, $\mathrm{P}<0.0001$.

Out of the $55 \mathrm{AKI} \mathrm{UO}_{\text {elec }}$ patients, $38 \%$ reached a maximum KDIGO score of stage 1 , and $62 \%$ reached a maximum severity of stage 2 or 3 . Out of the 25 patients with $\mathrm{AKI} \mathrm{SCr}, 68 \%$ of the patients had a maximum severity score of stage 1 and $32 \%$ reached stages 2 or 3 as their the maximum KDIGO severity score (Figure 2b).

Time to identification of $A K I$

Out of the 60 total AKI patients, the time to identify AKI using $\mathrm{UO}_{\text {elec }}$ criteria was significantly earlier than with SCr ( $\left.\mathrm{P}<0.0001\right)$ (Figure $3 a$ ). In the 20 patients that had AKI according to both criteria, time to AKI identification was significantly earlier by $\mathrm{UO}_{\text {elec }}$ as compared to $\mathrm{SCr}(\mathrm{P}<0.0001)$. Among this population, the

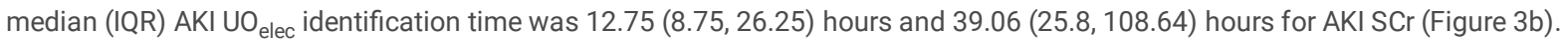

\section{Length of stay}

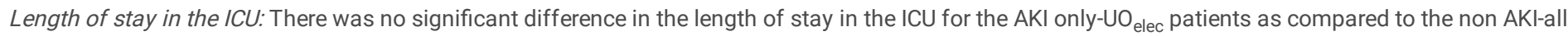
patients $(P=0.3354)$. Length of stay in the ICU for the AKI all-SCr patients was significantly longer than the $A K I$ only-UO ${ }_{\text {elec }}$ patients $(P=0.0043)(T a b l e ~ 2)$.

Length of stay in the hospital: The AKI all-SCr group had a median (IQR) length of stay in the hospital of $20.39(8.48,39.46)$ days. The AKI only-UO elec $_{\text {group }}$ had a similar LOS in the hospital with a median of $20.27(10.08,45.99)$ days. Although it did not reach significance, this was approximately 5 days longer than the non AKI-all patients, $14.92(8.88,30.46)$ days $(P=0.4210)$ (Table 2$)$.

Length of stay in the hospital with a cut-off below and above 70 years of age: Patients less than 70 years old in the $\mathrm{AKI}$ only-UO $\mathrm{elec}_{\mathrm{group}}$ had the longest median (IQR) hospital stay, $28.42(8.46,48.18)$ days, as compared to the AKI all-SCR, and non AKI-all groups of 23.84(13.82,38.72), and 16.31(10.5,31.25) days, respectively ( $P=0.9403$ and $P=0.655$, respectively) (Table 2$)$.

Sensitivity analyses for these parameters as time to discharge (taking into account censored data due to mortality) yielded similar results.

\section{Discussion}

A recent study in ICU and cardiac surgery patients compared consecutive hourly measurements of urine output versus a mean urine output over the time measured. The results found that averaging UO over time versus consecutive hourly measurements significantly overestimated the incidence of AKI in cardiac surgery patients. In the ICU patients it was shown that using a mean UO in comparison to the consecutively measured hours led to misclassification of the KDIGO severity stage (9). The RIFLE, AKIN, and KDIGO criteria for AKI have recognized the need to incorporate smaller time intervals for the assessment of kidney injury using UO $(2,16)$. Detection of oliguria is limited by the available tools, human error, and varying approaches to its definition. A reliable method for consecutive measurements of urine output would provide a consistent application of the KDIGO urine output criteria for diagnosis of kidney injury. In this study we demonstrated that consecutive electronically monitored UO identified significantly more cases of AKI according to the KDIGO criteria that were not identified by SCr alone. Additionally, in patients that fulfilled AKI definitions using both the SCr and UO criteria, $\mathrm{UO}_{\text {elec }}$ measurement identified $\mathrm{AKI}$ identified significantly earlier than SCr.

The advantage of continuous measurements of urine output was presented in a study showing oliguric periods as a predictor of higher mortality in critically ill patients. These authors discussed the need for a broader understanding of urine output as a physiological variable as opposed to one measured in set intervals (18). Alternatively, it has been argued that UO is too sensitive a biomarker for identifying AKI as oliguria may occur in response to normal physiological mechanisms $(17,18,19)$. However, many studies confirm that oliguria, even in the absence of a rise in creatinine, identifies patients who have worse long term outcomes, increased severity of AKI, and require more dialysis $(3,4.1,13,20)$.

Our study was blinded, and urine output for these patients was not documented in their records according to the electronic monitoring. Potential treatment course and ICU outcomes did not relate to consecutive monitoring of UO. This may explain why the patients with $\mathrm{AKI}_{\text {as }}$ defined by $\mathrm{UO}_{\mathrm{elec}}$ had a similar length of stay to that of the non AKI population. However, the extended time in the hospital after ICU discharge in the $\mathrm{AKI}$ only-UO $\mathrm{O}_{\text {elec }}$ patients $(>5$ days in the general population and 8 days in the under 70 group) compared to the non AKI patients, point to important clinical implications for earlier identification of AKI UO. Retrospective studies have shown a prolonged length of stay and higher mortality in the ICU and cardiac surgery patients that had AKI according to both the urine output and serum creatinine criteria $(8,21)$. Physicians in our study were not blinded to $\mathrm{SCr}$ measurements as with the UO ${ }_{\text {elec }}$ measurements, which may have contributed to the longer length of stay in the ICU observed in the AKI all-SCr group in our study. This may be further highlighted with the similar length of

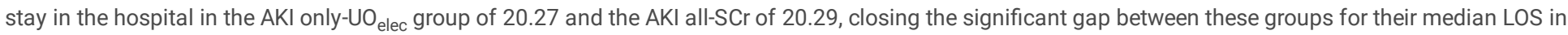
the ICU.

A retrospective study in over 15,000 adults compared intensive vs non-intensive monitoring of UO and intensive vs non-intensive SCr monitoring. Intensive UO monitoring was shown to be independently associated with improved survival to 30 days among patients developing AKI. Intensive monitoring of SCr had no effect on 30 day mortality associated with AKI. With or without AKI, patients who had intensive UO monitoring had significantly less cumulative fluid volume and fluid overload, and were significantly less likely to receive vasopressors over the first 72 hours of their ICU stay (22). Intensive monitoring in that study was considered a measurement recorded at least once every 3 hours and was exclusively manual monitoring of UO. Our study shows that continuous, consecutive hourly monitoring of urine output can provide a uniform application of KDIGO criteria to identify AKI early and in real-time. A consensus definition for early identification of acute kidney injury may enable earlier intervention and prevent progression of the disease (18). 


\section{Study limitation}

Due to the nature of the pilot study our patient population was limited in size. Follow-up after hospital discharge for readmissions within 3 months and 1 year mortality were too small for analysis. Further prospective studies using real-time continuous urine output monitoring on larger patient cohorts should be designed to assess the advantage of early detection of AKI with these criteria.

\section{Conclusion}

Electronic urine output monitoring provides a uniform definition for defining AKI patients in the ICU according to the KDIGO criteria. Application of KDIGO criteria for AKI using continuous monitoring of UO identifies more AKI patients, and identifies them earlier, than using the $\mathrm{SCr}$ criteria alone. This tool can enable the clinician to set protocol goals for earlier intervention for the treatment of AKI.

\section{Declarations}

\section{Ethics approval and consent to participate}

All methods were carried out in accordance with relevant guidelines and regulations.

Local IRB approval was obtained from the Hadassah Medical Center Helsinki ethics committee and informed consent was waived.

\section{Consent for publication}

Not applicable

\section{Availability of data and material}

The datasets used and/or analysed during the current study are available from the corresponding author on reasonable request.

\section{Competing interests}

Goldman A, Azran H, and Stern T are employees of RenalSense. Kirshenbom D is the head nurse of the GICU at Hadassah Medical Center and has disclosed no competing interests. Willner D was affiliated with Hadassah Medical Center in the Anaesthesiology Department at the time of the study and has disclosed no competing interests. Rosenthal $\mathrm{G}$ is affiliated with Hadassah Medical Center as the head of the Neurological ICU and has disclosed no competing interests.

\section{Funding}

RenalSense provided all equipment and for this study.

\section{Author contributions}

DW- Study conception, study design, data interpretation, and project manager. AG- review of data integrity, drafting of manuscript and preparation of figures. HA- internal review board submission, data collection set up and design. TS- Data collection, review of data integrity and support for statistical review by the outsourced biostatistics company. DK-Study design, patient selection. GR-Study design, study PI, manuscript review and edit. all authors reviewed the manuscript.

\section{Acknowledgement}

We would like to acknowledge Aliza Rozenberg and Ilan Yanuv from Global Statistics for their contribution to the statistical analysis of the data in this study. Thank you to the dedicated GICU nursing staff at Hadassah Medical Center for their cooperation and support of this study.

\section{References}

1. Kellum JA, Sileanu FE, Murugan R, Lucko N, Shaw AD, Clermont G. Classifying AKI by Urine Output versus Serum Creatinine Level. J Am Soc Nephrol. 2015 Sep;26(9):2231-8. doi: 10.1681/ASN.2014070724.

2. Section 2: AKI Definition. Kidney Int Supp/(2011). 2012 Mar;2(1):19-36. doi: 10.1038/kisup.2011.32.

3. Singbartl K, Kellum JA. AKI in the ICU: definition, epidemiology, risk stratification, and outcomes. Kidney Int. 2012 May;81(9):819-25. doi: 10.1038/ki.2011.339.

4. Luo X, Jiang L, Du B, Wen Y, Wang M, Xi X; Beijing Acute Kidney Injury Trial (BAKIT) workgroup. A comparison of different diagnostic criteria of acute kidney injury in critically ill patients. Crit Care. 2014 Jul 8;18(4):R144. doi: 10.1186/cc13977.

5. Bagshaw SM, Bellomo R. Early diagnosis of acute kidney injury. Curr Opin Crit Care. 2007 Dec;13(6):638-44. doi: 10.1097/MCC.0b013e3282f07570.

6. Galley HF. Can acute renal failure be prevented? J R Coll Surg Edinb. 2000 Feb;45(1):44-50. PMID: 10815380.

7. Perrone RD, Madias NE, Levey AS. Serum creatinine as an index of renal function: new insights into old concepts. Clin Chem. 1992 Oct;38(10):1933-53. PMID: 1394976. 
8. Allen JC, Gardner DS, Skinner H, Harvey D, Sharman A, Devonald MAJ. Definition of hourly urine output influences reported incidence and staging of acute kidney injury. BMC Nephrol. 2020 Jan 15;21(1):19. doi: 10.1186/s12882-019-1678-2.

9. Koeze J, Keus F, Dieperink W, van der Horst IC, Zijlstra JG, van Meurs M. Incidence, timing and outcome of AKI in critically ill patients varies with the definition used and the addition of urine output criteria. BMC Nephrol. 2017 Feb 20;18(1):70. doi: 10.1186/s12882-017-0487-8.

10. Macedo E, Malhotra R, Claure-Del Granado R, Fedullo P, Mehta RL. Defining urine output criterion for acute kidney injury in critically ill patients. Nephrol Dial Transplant. 2011 Feb;26(2):509-15. doi: 10.1093/ndt/gfq332.

11. Fujii T, Uchino S, Takinami M, Bellomo R. Validation of the Kidney Disease Improving Global Outcomes criteria for AKI and comparison of three criteria in hospitalized patients. Clin J Am Soc Nephrol. 2014 May;9(5):848-54. doi: 10.2215/CJN.09530913.

12. Cruz DN, Ricci Z, Ronco C. Clinical review: RIFLE and AKIN-time for reappraisal. Crit Care. 2009;13(3):211. doi: 10.1186/cc7759.

13. Bedford M, Stevens PE, Wheeler TW, Farmer CK. What is the real impact of acute kidney injury? BMC Nephrol. 2014 Jun 21;15:95. doi: 10.1186/14712369-15-95.

14. Harrois A, Soyer B, Gauss T, Hamada S, Raux M, Duranteau J; Traumabase ${ }^{\circledR}$ Group. Prevalence and risk factors for acute kidney injury among trauma patients: a multicenter cohort study. Crit Care. 2018 Dec 18;22(1):344. doi: 10.1186/s13054-018-2265-9.

15. Goldman A, Azran H, Stern T, et al. A novel electronic device for measuring urine flow rate: a clinical investigation. Clinical Medicine Insights: Trauma and Intensive Medicine. 2017 Aug;8: 1-6.org/10.1177/117956031730032

16. Lehner GF, Forni LG, Joannidis M. Oliguria and Biomarkers of Acute Kidney Injury: Star Struck Lovers or Strangers in the Night? Nephron. 2016;134(3):183190. doi: 10.1159/000447979.

17. Mehta RL, Kellum JA, Shah SV, Molitoris BA, Ronco C, Warnock DG, Levin A; Acute Kidney Injury Network. Acute Kidney Injury Network: report of an initiative to improve outcomes in acute kidney injury. Crit Care. 2007;11(2):R31. doi: 10.1186/cc5713.

18. Prowle JR, Liu YL, Licari E, Bagshaw SM, Egi M, Haase M, etal. Oliguria as predictive biomarker of acute kidney injury in critically ill patients. Crit Care. 2011 Jul 19;15(4):R172. doi: 10.1186/cc10318.

19. Klein SJ, Lehner GF, Forni LG, Joannidis M. Oliguria in critically ill patients: a narrative review. J Nephrol. 2018 Dec;31(6):855-862. doi: 10.1007/s40620018-0539-6.

20. Macedo E, Malhotra R, Bouchard J, Wynn SK, Mehta RL. Oliguria is an early predictor of higher mortality in critically ill patients. Kidney Int. 2011 Oct;80(7):760-7. doi: 10.1038/ki.2011.150.

21. Howitt SH, Grant SW, Caiado C, Carlson E, Kwon D, Dimarakis I, et al. The KDIGO acute kidney injury guidelines for cardiac surgery patients in critical care: a validation study. BMC Nephrol. 2018 Jun 25;19(1):149. doi: 10.1186/s12882-018-0946-x.

22. Jin K, Murugan R, Sileanu FE, Foldes E, Priyanka P, Clermont G, et al. Intensive Monitoring of Urine Output Is Associated With Increased Detection of Acute Kidney Injury and Improved Outcomes. Chest. 2017 Nov;152(5):972-979. doi: 10.1016/j.chest.2017.05.011.

\section{Tables}

Table 1. Patient characteristics 


\begin{tabular}{|c|c|c|}
\hline \multicolumn{3}{|c|}{ patient information $\mathrm{N}=95$} \\
\hline \multirow{2}{*}{$\begin{array}{l}\text { gender- } \\
\%(n)\end{array}$} & male & $67 \%(64)$ \\
\hline & female & $33 \%(32)$ \\
\hline \multirow[t]{2}{*}{ age } & mean (SD) & $59.3(19.7)$ \\
\hline & median (IQR) & $63(47.5,74)$ \\
\hline \multirow[t]{2}{*}{ weight } & mean (SD) & $79.8(16.6)$ \\
\hline & median (IQR) & $75(70,90)$ \\
\hline \multirow{8}{*}{$\begin{array}{l}\text { cause for admission- } \\
\%(n)\end{array}$} & surgical & $66 \%(63)$ \\
\hline & oncological & $12 \%(11)$ \\
\hline & burns & $4 \%(4)$ \\
\hline & trauma & $32 \%(30)$ \\
\hline & neurological & $21 \%(20)$ \\
\hline & infection/sepsis & $11 \%(10)$ \\
\hline & cardiological & $0 \%(0)$ \\
\hline & other & $14 \%(13)$ \\
\hline \multirow{11}{*}{$\begin{array}{l}\text { risk factors for AKI- } \\
\%(n)\end{array}$} & age $>70$ & $37 \%(35)$ \\
\hline & diabetes mellitus & $24 \%(23)$ \\
\hline & hypertension & $29 \%(28)$ \\
\hline & morbid obesity & $7 \%(7)$ \\
\hline & chronic liver disease & $7 \%(7)$ \\
\hline & congestive heart failure & $7 \%(7)$ \\
\hline & chronic lung disease & $12 \%(11)$ \\
\hline & Ischemic heart disease & $12 \%(11)$ \\
\hline & mechanical ventilation & $76 \%(72)$ \\
\hline & ianotropes & $44 \%(42)$ \\
\hline & chronic kidney disease & $1 \%(1)$ \\
\hline
\end{tabular}

Table 2. Time to discharge 


\begin{tabular}{|c|c|c|c|c|c|c|c|c|c|c|c|c|c|c|}
\hline & \multicolumn{7}{|c|}{ AKI all-SCr } & \multicolumn{4}{|c|}{ Added AKI only-UO } & \multicolumn{3}{|c|}{ non AKI-all } \\
\hline & Hospitalization & LOS in & $\mathbf{N}$ & $\begin{array}{l}\text { Mean } \\
(S D)\end{array}$ & $\begin{array}{l}\text { Median } \\
\text { (IQR) }\end{array}$ & Range & $\mathbf{N}$ & $\begin{array}{l}\text { Mean } \\
\text { (SD) }\end{array}$ & $\begin{array}{l}\text { Median } \\
\text { (IQR) }\end{array}$ & Range & $\mathbf{N}$ & $\begin{array}{l}\text { Mean } \\
\text { (SD) }\end{array}$ & $\begin{array}{l}\text { Median } \\
\text { (IQR) }\end{array}$ & Range \\
\hline \multirow{6}{*}{$\begin{array}{l}\text { All } \\
\text { patients }\end{array}$} & \multirow{4}{*}{$\begin{array}{l}\text { Initial } \\
\text { admission } \\
\text { (days) }\end{array}$} & ICU & 25 & 14.7 & 7.98 & \multirow{2}{*}{$\begin{array}{l}(2.04 \\
86.79)\end{array}$} & \multirow[t]{2}{*}{35} & 6.59 & 3.09 & \multirow{2}{*}{$\begin{array}{l}(1.09 \\
22.97)\end{array}$} & \multirow[t]{2}{*}{35} & 5.17 & 3.08 & \multirow{2}{*}{$\begin{array}{l}(1.09 \\
24.38)\end{array}$} \\
\hline & & & & $(17.91)$ & $\begin{array}{l}(4.28, \\
18.72)\end{array}$ & & & $(6.39)$ & $\begin{array}{l}(2.06 \\
8.02)\end{array}$ & & & $(5.03)$ & $\begin{array}{l}(1.86, \\
7.23)\end{array}$ & \\
\hline & & Hospital & 25 & 28.71 & 20.39 & $\begin{array}{l}(2.04 \\
11821)\end{array}$ & 35 & 28.79 & 20.27 & (2.42, & 35 & 21.34 & & $\begin{array}{l}(1.61 \\
7246)\end{array}$ \\
\hline & & & & $(27.44)$ & $\begin{array}{l}(8.48 \\
39.46)\end{array}$ & & & $(26.75)$ & $\begin{array}{l}(10.08, \\
45.99)\end{array}$ & & & $(17.6)$ & $\begin{array}{l}(8.88, \\
30.46)\end{array}$ & \\
\hline & \multirow{2}{*}{\multicolumn{2}{|c|}{$\begin{array}{l}\text { Total } \\
\text { hospitalization } \\
\text { days in } 3 \\
\text { months }\end{array}$}} & 25 & 32.63 & 23.42 & \multirow{2}{*}{$\begin{array}{l}(2.04 \\
118.21)\end{array}$} & \multirow[t]{2}{*}{35} & 32.93 & 22.04 & \multirow{2}{*}{$\begin{array}{l}(2.42 \\
104.99)\end{array}$} & \multirow[t]{2}{*}{35} & 23.09 & 16.23 & \multirow{2}{*}{$\begin{array}{l}\text { (1.61, } \\
72.46)\end{array}$} \\
\hline & & & & $(28.62)$ & $\begin{array}{l}(9.7 \\
55.56)\end{array}$ & & & $(29.08)$ & $\begin{array}{l}(10.08, \\
56.08)\end{array}$ & & & (18.22) & $\begin{array}{l}(9.4, \\
38.15)\end{array}$ & \\
\hline \multirow[t]{6}{*}{ Age $\leq 70$} & \multirow{4}{*}{$\begin{array}{l}\text { Initial } \\
\text { Admission } \\
\text { (days) }\end{array}$} & ICU & 12 & 10.86 & 7.92 & \multirow{2}{*}{$\begin{array}{l}(3.84 \\
30.63)\end{array}$} & \multirow[t]{2}{*}{21} & 6.32 & 3.09 & \multirow{2}{*}{$\begin{array}{l}(1.09 \\
22.97)\end{array}$} & \multirow[t]{2}{*}{27} & 5.58 & 3.96 & \multirow{2}{*}{$\begin{array}{l}(1.09 \\
24.38)\end{array}$} \\
\hline & & & & $(8.98)$ & $\begin{array}{l}(4.7, \\
11.35)\end{array}$ & & & $(6.25)$ & $\begin{array}{l}(2.72, \\
7.53)\end{array}$ & & & $(4.93)$ & $\begin{array}{l}(1.93 \\
7.45)\end{array}$ & \\
\hline & & Hospital & 12 & 27.45 & 23.84 & $(5.82$, & 21 & 33.31 & 28.42 & $(2.52$ & 27 & 23.81 & 16.31 & $(1.93$ \\
\hline & & & & $(17.91)$ & $\begin{array}{l}(13.82 \\
38.72)\end{array}$ & & & $(30.28)$ & $\begin{array}{l}(8.46, \\
48.18)\end{array}$ & & & & $\begin{array}{l}(10.5 \\
31.25)\end{array}$ & \\
\hline & \multirow{2}{*}{\multicolumn{2}{|c|}{$\begin{array}{l}\text { Total } \\
\text { hospitalization } \\
\text { days in } 3 \\
\text { months }\end{array}$}} & 12 & 31.45 & 28.79 & \multirow{2}{*}{$\begin{array}{l}(5.82 \\
70.42)\end{array}$} & \multirow[t]{2}{*}{21} & 38.12 & 34.44 & \multirow{2}{*}{$\begin{array}{l}(2.52 \\
104.99)\end{array}$} & \multirow[t]{2}{*}{27} & 26.07 & 18 & \multirow[t]{2}{*}{$\begin{array}{l}(6.48, \\
72.46)\end{array}$} \\
\hline & & & & $(21.64)$ & $\begin{array}{l}\text { (15.37) } \\
47.72)\end{array}$ & & & $(32.47)$ & $\begin{array}{l}(8.46 \\
56.48)\end{array}$ & & & $(17.59)$ & $\begin{array}{l}(12.54 \\
40.25)\end{array}$ & \\
\hline \multirow[t]{6}{*}{ Age>70 } & \multirow{4}{*}{$\begin{array}{l}\text { Initial } \\
\text { Admission } \\
\text { (days) }\end{array}$} & ICU & 13 & 18.26 & 9.7 & \multirow{2}{*}{$\begin{array}{l}(2.04 \\
86.79)\end{array}$} & 14 & 7.00 & 3.68 & $(1.69$ & 8 & 3.8 & 1.83 & $(1.21$ \\
\hline & & & & $(23.22)$ & $\begin{array}{l}(3.52 \\
23.15)\end{array}$ & & & $(6.81)$ & $\begin{array}{l}(1.93 \\
13.27)\end{array}$ & & & $(5.49)$ & $\begin{array}{l}(1.57 \\
2.54)^{\prime}\end{array}$ & \\
\hline & & Hospital & 13 & 29.88 & 18.72 & $\begin{array}{l}(2.04 \\
11821)\end{array}$ & 14 & $\begin{array}{l}22.01 \\
(19.43)\end{array}$ & 13.31 & $\begin{array}{l}(2.42 \\
65.29)\end{array}$ & 8 & $\begin{array}{l}13.02 \\
(1771)\end{array}$ & 6.81 & $\begin{array}{l}(1.61, \\
5533)\end{array}$ \\
\hline & & & & (34.78) & $\begin{array}{l}(6.49 \\
41.04)\end{array}$ & & & & $\begin{array}{l}(11.29, \\
22.35)\end{array}$ & & & & $\begin{array}{l}(3.7 \\
13.1)\end{array}$ & \\
\hline & $\begin{array}{l}\text { Total } \\
\text { hospitalization }\end{array}$ & & 13 & 33.73 & 20.39 & $\begin{array}{l}(2.04 \\
118.21)\end{array}$ & 14 & 25.15 & 14.88 & $\begin{array}{l}(2.42 \\
65.99)\end{array}$ & 8 & 13.02 & 6.81 & $\begin{array}{l}(1.61 \\
55.33)\end{array}$ \\
\hline & $\begin{array}{l}\text { days in } 3 \\
\text { months }\end{array}$ & & & (34.74) & $\begin{array}{l}(8.48 \\
55.56)\end{array}$ & & & $(21.92)$ & $\begin{array}{l}(11.29 \\
36.35)\end{array}$ & & & (17.71) & $\begin{array}{l}(3.7 \\
13.1)\end{array}$ & \\
\hline
\end{tabular}

Table 2. Comparison of time to discharge from the ICU and the hospital, and readmissions to the hospital within 3 months in patients with AKI according to SCr and UO (all-SCr), AKI according to UO only (only-UO) and non-AKI. The groups were also divided and compared according to the cut-off of above and below 70 years old.

\section{Figures}




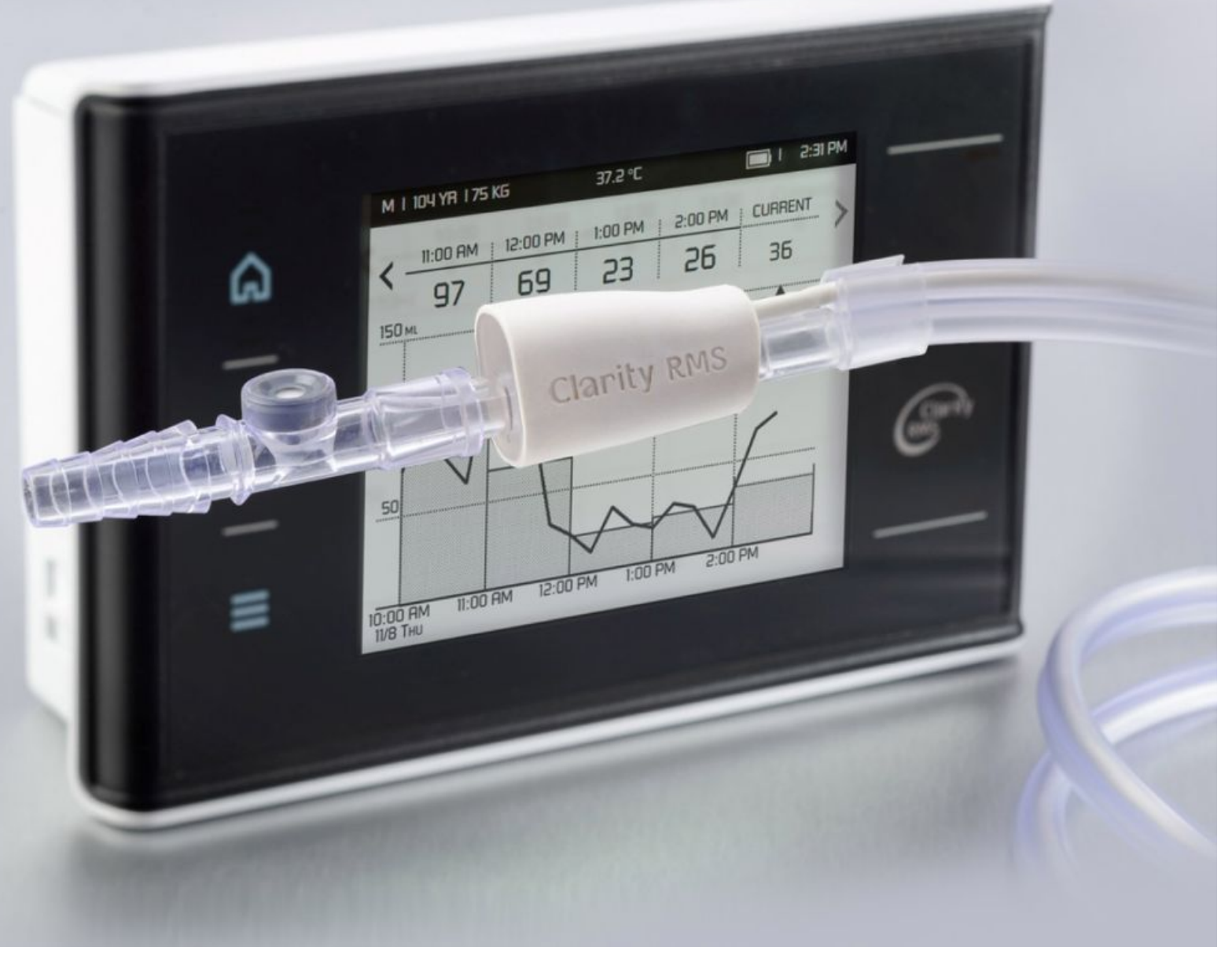

Figure 1

The RenalSense ${ }^{\mathrm{TM}}$ Clarity RMS Sensor Kit ${ }^{\mathrm{TM}}$ integrates the sensor into the standard urinary drainage tube and monitors urine output as it exits the Foley catheter. The data is communicated to the Clarity RMS Console through a cable integrated within a custom-designed drainage tube to the bag and then to the Console, mounted on the footboard.

2a.

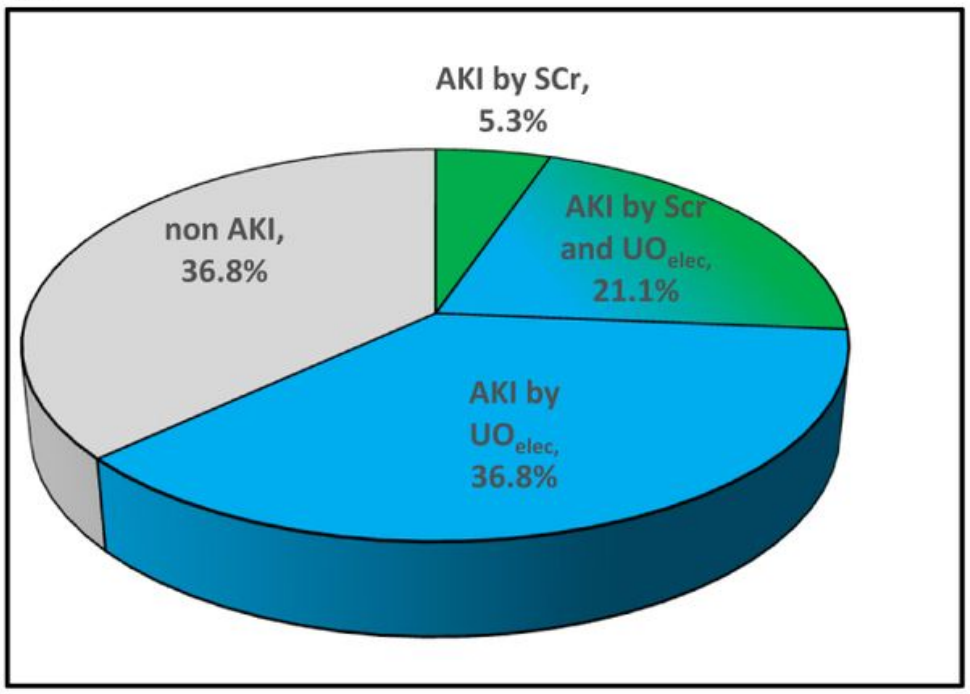

$2 b$.

\begin{tabular}{|c|c|c|c|c|c|c|}
\hline \multirow{2}{*}{\multicolumn{2}{|c|}{$\begin{array}{l}\text { Severity staging } \\
\text { for } A K I\end{array}$}} & \multicolumn{4}{|c|}{ UO $_{\text {elec }}$ stages } & \\
\hline & & 1 & \multirow{2}{*}{$\begin{array}{l}2 \\
10\end{array}$} & \multirow{2}{*}{$\begin{array}{l}3 \\
1\end{array}$} & \multirow{2}{*}{$\begin{array}{l}\text { non } \\
\text { AKI } \\
4\end{array}$} & \\
\hline \multirow{4}{*}{$\begin{array}{l}\mathrm{SCr} \\
\text { stages }\end{array}$} & 1 & 2 & & & & 17 \\
\hline & 2 & & 2 & 1 & & 3 \\
\hline & 3 & 1 & 3 & & 1 & 5 \\
\hline & non AKI & 18 & 16 & 1 & 35 & 70 \\
\hline & & 21 & 31 & 3 & 40 & \\
\hline
\end{tabular}

Figure 2

a. Identification of AKI in the study population according to UOelec and SCr criteria as defined by the KDIGO guidelines. b. AKI severity in the study population according to the KDIGO criteria. 
$3 a$.

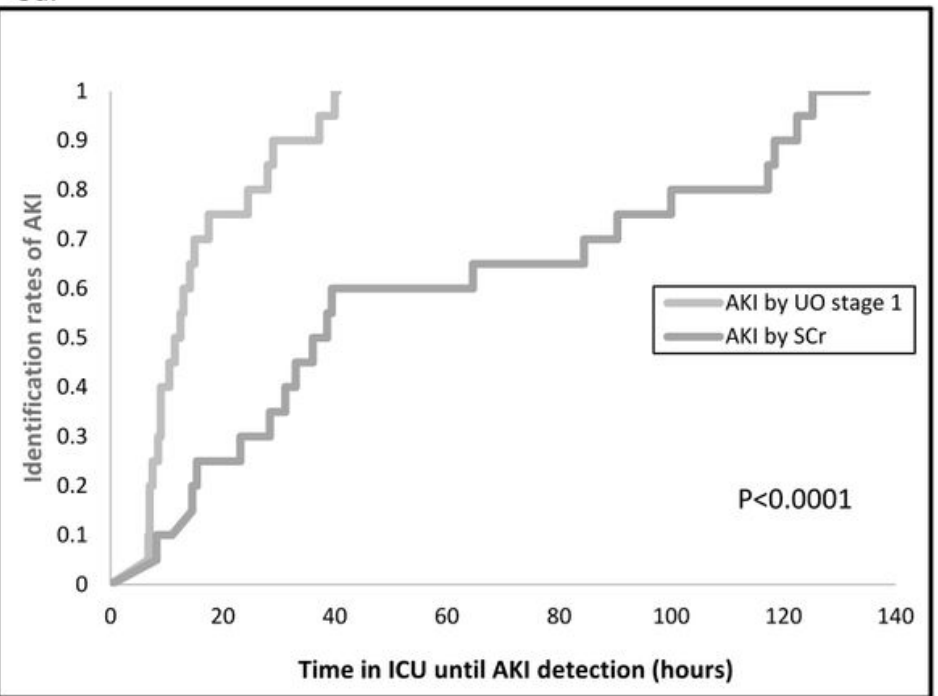

Figure 3

a. Kaplan Meir curve for time to identification rates of AKI for 60 patients identified applying UOelec or SCR. b. Kaplan Meir curve for time to identification of AKI in 20 patients applying both SCr and UOelec criteria
$3 b$.

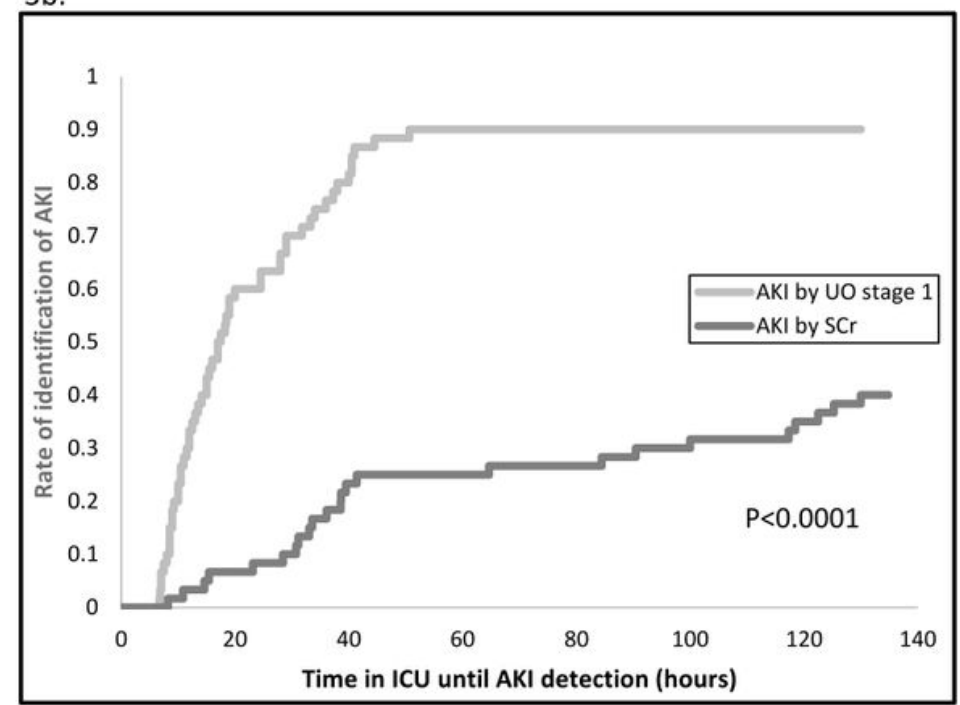

